\title{
HISTÓRIA, CINEMA E ESTUDOS DE GÊNERO: ENTREVISTA COM O HISTORIADOR ALBERTO DA SILVA
}

\author{
Cintia Lima Crescêncio* \\ Cristina Scheibe Wolff***
}

O historiador Alberto da Silva atua como professor no Departamento de Estudos Lusófonos na Universidade de Rennes 2 e na Universidade de Paris 7 - Diderot, na França. É integrante do grupo de pesquisa CRIMIC (Centre de Recherche Interdisciplinaire sur les Mondes Ibériques Contemporains) e da Equipe de Recherche Interlangues "Mémoires, identités, Territoires" da Univeristé Rennes 2. Tem atuado no campo dos estudos de gênero e cinema com ênfase nas representações de masculino e feminino nos filmes produzidos durante a ditadura no Brasil.

Ele esteve em Florianópolis em agosto de 2011 para dar duas conferências sobre seus trabalhos enfocando cinema, estudos históricos e gênero, e aproveitamos para entrevistá-lo para a Revista Esboços. Sua perspectiva é inovadora tanto para os estudos de gênero como para a historiografia brasileira, pela metodologia de utilização do cinema como fonte que respeita o saber cinematográfico, através da inclusão de aspectos técnicos da montagem das cenas, da utilização da técnica que faz descrições detalhadas de cada cena com todos os seus elementos: cenário, foco das câmeras, posicionamentos dos objetos e dos personagens, luz, cores, som, entre outros. Muitos desses elementos se integram na análise e deixam ver uma linguagem complexa, mas muito atual na construção histórica e crítica do gênero.

Nesta entrevista, Alberto da Silva nos conta de suas descobertas metodológicas na análise fílmica feitas por um historiador, da necessidade da interdisciplinaridade, das potencialidades do uso do gênero na análise histórica do cinema, da importância do contexto histórico para esta análise e das possibilidades do uso didático do cinema e os cuidados que temos que tomar.

* Mestranda no Programa de Pós-Graduação em História da Universidade Federal de Santa Catarina - UFSC. E-mail: cintialima23@gmail.com

** Professora no Departamento de História da Universidade Federal de Santa Catarina - UFSC.

E-mail: cristiwolf@gmail.com 


\section{Cristina Wolff e Cintia Lima: Como você começou a pesquisar cinema?}

Alberto da Silva: Quando eu comecei a procurar um tema para minha monografia, porque minha idéia era fazer mestrado e doutorado, eu queria fazer um trabalho que estivesse relacionado à arte, à cultura. Eu fui ator, trabalhei no teatro profissional durante cinco anos, e eu queria encontrar um caminho, uma ponte entre esta atividade e meu trabalho como historiador. Eu comecei a procurar um tema e a idéia inicial passava pelas peças de Nelson Rodrigues que eu já havia encenado como ator e de quem a obra eu já conhecia bastante. De início procurei entender o impacto dessas peças durante a época da ditadura: quais foram os debates? Mas, como historiador precisa de fontes, constatei que não existiam essas fontes, não localizei nada nos documentos em que pesquisei. Em compensação, localizei um debate muito presente sobre as adaptações de Nelson Rodrigues para o cinema, notadamente, "Toda nudez será castigada", de Arnaldo Jabor de 1972. Então pensei que poderia analisar o filme, o que sugeri a minha orientadora Alcileide Cabral, professora da Universidade Federal Rural de Pernambuco, com auxílio da professora Regina Behar que é professora da Universidade da Paraíba. Ambas aceitaram essa empreitada de analisar o filme "Toda nudez será castigada" quanto às representações do masculino e do feminino. Após ter terminado a monografia, Alcileide e Regina me disseram que ainda havia muitas questões interessantes a serem tratadas. Foi quando veio a idéia de continuar e desenvolver este trabalho no doutorado. A pesquisa muitas vezes nos leva para lugares que não imaginávamos inicialmente.

CW e CL: Qual a perspectiva da sua tese sobre cinema, história e gênero?

AS: A minha proposta na tese é interdisciplinar, muito de acordo com o que Douglas Kellner aponta como importante, a interdisciplinaridade no trabalho com esse objeto, o cinema. Eu trabalho com cinema, mas, por exemplo, eu recorri aos geógrafos para entender essa questão do espaço. Não tem como entender espaço se a gente não utiliza algumas referências da geografia. A casa, que nas análises dos filmes de Arnaldo Jabor tem um papel fundamental, todas essas questões ligadas ao espaço, são geógrafos que vão nos ajudar a pensar.

CW e CL: Quais os principais desafios para historiadoras e historiadores que desejam explorar o cinema como objeto e fonte histórica?

AS: Em primeiro lugar eu acredito que os desafios aparecem dependendo da proposta e do objeto, da maneira como você vai trabalhar em relação ao cinema. Eu vou me explicar. Por exemplo: você pode trabalhar com economia, entender a produção econômica do cinema, você pode abrir várias 
possibilidades. Na minha perspectiva, de representação de gênero, raça e classe, que eu tentei abarcar, a maior dificuldade é ir nessa perspectiva do Douglas Kellner, colocando os filmes no espaço geral, ou global, como diria Edward Burcombe, no sentido de compreender a produção, elaborar uma análise textual ou fílmica crítica e, finalmente, perceber como os filmes foram recebidos, vistos, compreendidos. Eu persegui bastante esse processo de produção. Eu não penso gênero separado da história, separado da geografia, da lingüística, da psicanálise, etc, eles estão ligados. O desafio é ter o cuidado com a produção, pensar na produção do filme a partir da distribuição, da análise fílmica, dentro da análise histórica e pensar como esse filme foi recebido. Não seria um estudo de recepção, mas a busca pelos sentidos que foram dados a esse filme. Em seguida, na escrita, a articulação desses três pontos. Esse é o principal desafio.

CW e CL: E o desafio de trabalhar com uma perspectiva interdisciplinar para um historiador, como se apresenta?

AS: Essa questão complementa o que eu disse anteriormente. Se você planeja fazer uma análise fílmica, você tem que aprender a utilizar os elementos dessa metodologia. Quando eu comecei o trabalho eu não tinha formação em cinema, e sim em história. Quando eu cheguei em Paris para fazer o doutorado, a professora Nancy Berthier disse: seu trabalho é muito bom, mas isso pode ser tanto uma análise literária quanto fílmica. Quando o historiador vai trabalhar com o filme, ele tem que conhecer a estética do filme, a análise fílmica, ele tem de se impregnar dessas questões, noções de câmera, de fotografia. Não estou dizendo que é preciso ser um especialista, mas esse vocabulário é importante no momento da análise. Hoje existem muitos historiadores que deram elementos e ferramentas teóricas importantes para o estudo do cinema, como o Christian Delage e Vincent Guigueno, assim como os estudos culturais que nos oferecem muitas ferramentas interessantes. Volto a repetir Douglas Kellner, que propõe essa ligação, como Michel Foucault já propunha uma caixinha de ferramentas em que vou pegar a ferramenta que vai me servir para resolver esse processo na análise.

CW e CL: Na sua opinião por que a história é resistente à apropriação do uso do cinema como fonte e objeto histórico, como já aconteceu com outros documentos, como é o caso da imprensa.

AS: Será que quando eu analiso um documento que foi redigido no século XIX também não devo considerar sua produção? Existe um contexto de produção, existe uma pessoa que escreveu o documento, existe o contexto histórico em que 
esse documento foi feito, existem as intenções e as escolhas dessa pessoa. Você não redige um documento por acaso, existe uma escolha. $\mathrm{O}$ diretor escolheu os códigos, ele escolheu o que e como filmar. Depois esse diretor que escolheu esses códigos vai estar sujeito a outras significações, as significações que eu vou dar a esse filme, como receptor desse produto. Será que tentar compreender as significações de um produto cultural dentro da história não é importante para o historiador? Por exemplo: os filmes de Arnaldo Jabor "Eu te amo" (1981) e "Eu sei que vou te amar" (1985) são produções completamente ligadas à época em que foram produzidas. Digo isso no sentido de produção, de divulgação, de distribuição, de recepção em relação à crítica, à população, ao momento político-econômico-social que o Brasil estava vivendo. Isso não interessa ao historiador? Antes de começar meu trabalho de pesquisa eu tinha uma visão dos filmes, eu tinha idéias pré-concebidas, mas depois da análise minha percepção mudou completamente e eu fiquei surpreendido comigo mesmo. Existe uma construção fílmica e um aparato técnico e temos que trabalhar com isso.

CW e CL: Quais as contribuições o cinema pode agregar ao campo dos estudos de gênero dentro de um ponto de vista histórico?

AS: O campo dos estudos de gênero não é separado da história, que não é separado da economia e de outras áreas. A construção e a representação do gênero, pelo que pude perceber no meu trabalho, estão articuladas a várias questões. No meu caso específico está articulado ao cinema, à cultura, à economia e à política. Talvez seja esse um dos motivos da resistência em relação à perspectiva de gênero. Eu não sei se posso afirmar que o campo dos estudos de gênero é independente, global. Essa contribuição é inerente aos estudos históricos. Podemos estudar gênero, mas relacionar com classe, com raça, com indústria cultural, com economia. Gênero é relacional.

CW e CL: Você tem trabalhado com cinema produzido durante a época da ditadura civil-militar brasileira, o mesmo período de emergência dos feminismos de segunda onda no Brasil. As movimentações feministas afetaram os modos de fazer cinema de diretoras e diretores que não se engajavam, necessariamente, na causa levantada por feministas?

AS: Essa questão tem que ser colocada no período. É preciso sair da nossa visão e mergulhar no período. Na realidade brasileira da época, o feminismo era profundamente criticado, então, uma cineasta assumir o rótulo de feminista significava a perda de muitas possibilidades: de exibição, de produção, de público. Esse período é diferente de agora que existe um público que gosta 
dos filmes com temática queer. É preciso pensar que é uma indústria cultural, que gera um produto, uma mercadoria. Em segundo lugar, a emergência do feminismo no Brasil é muito complexa, porque por um lado a direita não aceitava as idéias feministas em função da tríade: pátria, Deus e família, e por outro lado, a esquerda não aceitava porque considerava essas idéias burguesas. Em compensação, o feminismo, de uma maneira geral, foi uma revolução que mudou a sociedade, influenciou sim esse cinema. Um dos exemplos é o caso de Arnaldo Jabor. A partir dos anos 80 ele vai colocar em pauta a questão da identidade masculina e vai repensar essa questão; vai se perguntar: a minha subjetividade, onde fica? Com certeza sente-se isso na produção cinematográfica no Brasil, como no mundo em geral. Mas, durante a minha pesquisa eu queria muito achar críticas feitas por feministas a esse cinema, mas não localizei muitas. Com exceção de algumas encontradas na revista Nosotras. Pode haver, mas não encontrei nos arquivos.

CW e CL: Sua pesquisa refletiu sobre o cinema de Ana Carolina, como você demarcaria sua forma de fazer cinema? É um cinema feminista? É um cinema especificamente feito por uma mulher? Mesmo que ela não se identifique como feminista, é possível apontarmos questões caras ao feminismo, principalmente na sua trilogia "Das tripas coração", "Mar de Rosas" e "Sonho de Valsa"?

AS: Observando os documentos com os quais eu tive contato e pude pesquisar, nos anos 80 e 90 acontecem alguns congressos de cineastas e diretoras discutindo o cinema "da mulher" em que Ana Carolina participava. Por que os anos 80 ? Nos final dos anos 80 começa acontecer uma institucionalização do movimento feminista e as mulheres atuaram bastante politicamente, inclusive Ana Carolina, contudo, ela não se diz feminista. O cinema de Ana Carolina é um cinema de autor. Ela subverte a maneira de fazer cinema, mas eu sou um pouco reticente em falar de cinema masculino ou feminino porque se corre o risco da essencialização, de voltar ao biológico. Em compensação, nós somos produtos de uma sociedade. Como diz Olavo Bilac, o artista não está em uma torre de marfim trancafiado, ele faz parte de uma sociedade e tem os códigos com os quais ele vai criticar e descrever essa sociedade. Existem algumas diretoras que fizeram filmes que muito deixaram a desejar na representação do masculino e do feminino, principalmente do feminino, não conseguindo elaborar uma estratégia para romper com uma forma narrativa patriarcal. Ao mesmo tempo, eu vi alguns filmes feitos por homens que propõem estratégias textuais interessantes para se pensar a função narrativa em relação às questões de gênero. Eu sou reticente a essa idéia de filme feminino, filme feminista, filme masculino. O filme de Tisuka Yamasaki "Parahyba mulher macho" (1982), 
diante de uma análise fílmica, deixa muito a desejar ao tratar a história de uma feminista, e é dirigido por uma mulher que, em seguida, produz "Pátriamada" (1985), propondo questões excelentes com relação à representação do gênero. O cinema de Ana Carolina é um cinema de autor em que as personagens são o alter-ego da diretora. A partir do momento que nós temos um filme de autor feito por uma diretora, sendo o personagem principal o alter ego da diretora, talvez aí possamos ter outras possibilidades de representação do que podemos entender do feminino ou do masculino em dada sociedade. Por outro lado, no "Pátriamada", o alter ego de Tisuka é um diretor homem, que é interpretado por Buza Ferraz, uma personagem que é um cineasta que busca fazer cinema no Brasil, com todas as dificuldades, inclusive criando um filho sozinho.

CW e CL: Existe muita diferença entre Brasil e França no que tange ao uso do cinema como fonte e na área de estudos de gênero?

AS: O que eu posso dizer em relação a minha experiência é que um fator importante de ter ido para a França foi, além de minha orientadora, Maria Graciete Besse, o contato com alguns seminários, com Nancy Berthier e com Geneviève Sellier que hoje é uma referência dos estudos de gênero no cinema na França. Isso foi importante. Por outro lado, nós temos no Brasil algumas referências, artigos, livros, traduzidos para o português que não são traduzidos para o francês. No início da pesquisa conversei muito com Geneviève Sellier, ela foi muito importante na elaboração da tese. Ela me deu uma lista em que constava Judith Butler que ainda não havia sido traduzida na França, porém havia sido traduzida no Brasil. Essa possibilidade de acesso é importante.

CW e CL: $O$ cinema pode ser usado como fonte histórica e também como instrumento didático. Como trabalhar com cinema como ferramenta didática?

AS: Em minha opinião, talvez uma possibilidade seja a articulação com a área da pedagogia. Devem existir laboratórios que trabalhem com essas questões. Falta isso à formação do professor, não só de história, mas de geografia, de literatura, de português, uma vez que em todas essas disciplinas podemos utilizar muito o cinema. É preciso informar-se, aprender, não é apenas um exercício de ver o filme. Lembro do filme "Anastásia" (1997), uma produção de Disney, um desenho animado histórico que mostra o comunismo que chega, mas elabora uma série de significações quando constrói a idéia de comunista. A monarquia é dada como boa, como vítima, e o comunismo é um monstro que transforma a realidade em escuridão. O professor precisa ter as ferramentas para poder analisar esse filme, decodificar, mas isso precisa ser aprendido. 
Qual seria a solução? Elaboração de programas com pessoas capacitadas para preparar esses professores. Há alguns anos, na França, umas amigas que trabalham com cinema foram convidadas pela Education National para fazer palestras com professores, munidas de todo o material para mostrar como trabalhar com o cinema enquanto objeto didático: decupagem, análise fílmica, iluminação, contexto de produção e de recepção. Os professores podem ser assim, portanto, os multiplicadores. 